\title{
ANALISIS PEMASARAN USAHATANI CABAI MERAH KERITING DI KELURAHAN SEI SELINCAH KECAMATAN KALIDONI PALEMBANG
}

\author{
Endah Novitarini*1) 11 \\ 1)Dosen Jurusan Agribisnis Fakultas Pertanian Universitas Sjakhyakirti \\ *)Penulis untuk korespondensi: endahnovitarini52@gmail.com
}

\begin{abstract}
This research is titled marketing analysis of curly red chili farming in Sei Selincah Subdistrict Kalidoni Palembang as for the purpose of this research is to find out: 1. to edit the marketing channel inKelurahan Sei Selincah District Kalidoni 2. How much is the marketing cost in Sei Selincah Subdistrict Kalidoni 3. Margin Marketing in Sei Selincah Subdistrict kalidoni 4. Farmer's share in farmers

This research was conducted in Sei Selincah SubDistrict, Kalidoni, Palembang, which began in January 2020. The research method used is the survey method of keriring red chili farmers in Kelurhan Sei Selicah District Kalidoni Palembang. The method of withdrawal of examples is done in a segaja (purposive) with the number of semple as many as 15 farmers examples, while the method of retrieving marketing institutions using snowboll sampling (snowball rolling).

Based on the results of the research is that there are 3 marketing channels of curly red chilies in Sei Selincah Village consisting of three marketing channels, namely a) farmers-merchants village-consumer collectors, $b$ ) farmers - large traders - retailers - consumers, c) farmers - big collectors - lemabang markets - retailers consumers. The marketing cost of channel 1 is Rp.570,00 channel II Rp.740,00 channel III Rp. 733.33, Channel I marketing margin Rp.5000,00, channel II Rp.6.500,00 and channel III Rp. 7.667.00 next farmer share on channel I 85.7 percent followed channel II 71.1 percent and channel III 58.82 percent.
\end{abstract}

Keywords : marketing channels, marketing costs, marketing margins, curly red chilies

\begin{abstract}
ABSTRAK
Penelitian ini adalah bertujuan untuk: 1. mengidentifikasi saluran pemasaran di Kelurahan Sei Selincah Kecamatan Kalidoni 2. Berapa besar biaya pemasaran di Kelurahan Sei Selincah Kecamatan Kalidoni 3. Margin Pemasaran di Kelurahan Sei Selincah Kecamatan kalidoni 4. Farmer's share yang di petani

Penelitian ini lakukan di Kelurahan Sei Selincah Kecamatan Kalidoni Kota Palembang yang dimulai pada bulan Januari 2020. Metode penelitian yang digunakan adalah metode survei terhadap petani cabai merah keriring di Kelurhan Sei Selicah Kecamatan Kalidoni Kota Palembang. Metode penarikan contoh dilakukan secara segaja (purposive) dengan jumlah semple sebanyak 15 petani contoh, sedangkan metode pengambilan lembaga pemasaran menggunakan snowboll sampling (bola salju mengelinding).

Berdasarkan hasil penelitian adalah bahwa ada 3 saluran pemasaran cabai merah keriting di Kelurahan Sei Selincah terdiri dari tiga saluran pemasaran yaitu a) petani-pedagang pengepul desa-konsumen, b) petani pedagang besar - pedagang pengecer - konsumen, c) petani - pedagang pengepul besar - pasar lemabang - pedagang pengecer - konsumen. Biaya pemasaran saluran 1 adalah Rp.570,00 saluran II Rp.740,00 saluran III Rp. 733,33, Margin pemasaran saluran I Rp.5000,00, saluran II Rp.6.500,00 dan saluran III Rp. $7.667,00$ selanjutnya farmer share pada saluran I 85,7 persen di ikuti saluran II 71,1 persen dan saluran III 58.82 persen.
\end{abstract}

Kata kunci : saluran pemasaran, biaya pemasaran, margin pemasaran, cabai merah keriting

\section{PENDAHULUAN}

Pertanian merupakan sektor yang sangat berperan dalam kehidupan manusia. Ketersediaan sumber pangan untuk makhluk hidup ditentukan oleh adanya kegiatan dibidang pertanian. Masyarakat Indonesia banyak yang bergantungpada pertanian sebagai sumber mata pencaharian untuk memperolehpendapatan dan memenuhi kebutuhan sehari-hari cabai merupakan salah satu komoditas 
hortikultura yang banyak dibutuhkan konsumen di Indonesia, karena merupakan salah satu dari sembilan kebutuhan pokok masyarakat, dengan tingkat konsumsi yang cenderung meningkat setiap tahunnya. Pada tahun 2010 permintaan akan cabai nasional untuk cabai merah mencapai 1.220 .088 ton dengan rata rata konsumsi Cabai perkapita mencapai $0,43 \mathrm{~kg} / \mathrm{kapita} / \mathrm{bulan}$, sehingga konsumsi perkapita per tahun penduduk Indonesia mencapai (4-5) kg (Rostini, 2011).

Siklus kebutuhan cabai di Indonesia meningkat menjelang event tertentu, seperti memasuki bulan puasa dan lebaran, natal dan tahun baru. Pada saat-saat tertentu,permintaan cabai yang tinggi diiringi dengan harga yang melambung, terutama jika event - event tersebut bertepatan dengan musim hujan. Biasanya pada musim hujan petani yang menanam cabai hanya sedikit dan banyak gagal panen akibat serangan hama dan penyakit. Akibatnya, keberadaan cabai di pasaranmenjadi langka dan secara otomatis harganya melonjak tinggi.

(Wiryanta, 2011).

Jumlah pasokan cabai merah keriting (Capsicum annum L) di pasaran yang tidak mampu memenuhi permintaan konsumen mengakibatkan hargamelambung tinggi. Hal ini disebabkan cabai merah keriting telah menjadi kebutuhan penting bagi sebagian besar Masyarakat yang belum dapat tergantikan dengan komuditas lain. selain sebagai komuditi yang mempunyai kapasitas manaikkan taraf pendatan petani, cabai merah keriting juga mempunyai nilai ekonomis yang tinggi.cabai merah meriting. merupakan tanaman perdu dari family terong-terongan. Cabai berasal dari Benua Amerika tepatnya daerah Peru dan menyebar ke Negaranegara Benua Amerika, Eropa, dan Asia termasuk Indonesia.(Miskun, 2013).

Tanaman cabai merah keriting merupakan jenis komoditi petanian yang berprospek cerah, karena peminat terhadap komoditi ini cukup tinggi. cabai merah keriting dibutuhkan manusia, karena cabai merah keriting mempunyai kandungan vitamin C (karbohidrat dan mineral pada cabai merah keriting tidak dapat disubtitusikan untuk makanan pokok). Cabai merah keriting adalah komoditi hortikutura penting di Indonesia yang dikomsumsi sebagian besar penduduk tanpa memperhatikan tingkat social. Selain sebagai komuditi yang mempunyai kapasitas menaikkan taraf pendapatan petani, cabai merah keriting juga mempunyai nilai ekonomis yang tinggi (Balai Penelitian dan Pengembangan Pertanian Jakarta, 2015).
Komoditi hortikultura pada umumnya, Hasil hortikutura merupakan barang pasaran sehari-hari, berbeda dengan hasil pertanian yang lain yang merupakan barang timbunan, yang dapat disimpan dalam waktu yang cukup lama, peranan pemasaran pada komiditi tanaman cabai merah keriting memberi kontribusi penting dalam peningkatan kinerja usahatani cabai secara keseluruhan mengingat sifat unik komoditi hortikutula pada umumnya mudah membusuk dan rusak. Sifat-sifat ini mununtut adanya perlakuan yang sangat khusus seperti pengangkutan yang berhati-hati, pengepakan yang baik, penyimpanan dengan suhu yang sesuai dengan metode pegawetan lain sehingga komoditas dimaksud dapat bertahan dalam waktu yang cukup lama.Untuk menyapaikan barang dari produsen ke konsumen melalui seluran pemasaran yaitu melalui suatu badan atau lembaga-lembaga yang menyelenggarakan kegiatan pemasaran (Saefuddin, 2004).

Menurut Kartasapoetra (2005), bahwa kelembagaan pemasaran yang berperan dalam memasarkan komoditas pertanian hortikutura dalat mencakup petani, pedagang pengumpul, pedagang perantara/grosir dan pedagang pengencer. Kelembagan pemasaran yang berperan dalam pemasaran komoditi hortikutura adalah berupa pasar Tradisional, pasar modern dan pasar industri.

Pendapatan adalah seluruh penerimaan baik berupa uang maupun berupa barang yang berasal dari pihak lain maupun hasil industri yang dinalia atas dasar sejumlah uang dari harta yang berlaku saat itu. Pendapatan merupakan sumber penghasilan seseorang untuk memenuhi kebutuhan sehari-hari dan sangat penting artinya bagi kelangsungan hidup dan penghidupan seseorang secara langsung mau pun tidak langsung (Suroto, 2000).

Kelurahan Sei Selincah Kecamatan Kalidoni Palembang merupakan salah satu tempat pertanian yang mempunyai lahan 1200 hektar dan 1 kelompok tani terdiri 15 petani. Berdasarkan hasil pengamatan/surver lapangan di Kelurahan Sei Selincah Kecamatan Kalidoni permasalahan tanaman Cabai Merah Keriting salah satunya pemasaran, margin pemasaran dan farmer's share dan kontribusi usahatani terhadap pendapatan keluarga.

Berdasarkan uraian diatas, maka masalah yang dijadikan sasaran dalam penelitian ini adalah:

1. Bagaimana saluran pemasaran cabai merah keriting yang terdapat di Kelurahan Sei Selincah Kecamatan Kalidoni Kota Palembang? 
2. Berapa besar biaya pemasaran, margin pemasaran dan farmer's share yang diterima oleh petani?

Adapun tujuan dari penelitian ini adalah :

1. Untuk menginditifikasi berbagai macam saluran pemasaran cabai merah keriting Kelurahan Sei Selincah Kecamatan Kalidoni Kota Palembang.

2. Untuk menganalisis besar nya biaya pemasaran, margin pemasaran dan farmer's share yang diterima petani dan lembaga pemasaran dari masing-masing saluran pemasaran.

3. Untuk menghitung besarnya kontribusi pendapatan usahatani cabai merah keriting.

Sedangkan manfaat dari penelitian ini adalah :
1. Sebagai bahan informasi bagi pihak-pihak yang berkepentingan tentang pemasaran cabai merah keriting dan kontribusi usahatani terhadap pendapatan keluarga.

2. Sebagai bahan kepustakaan bagi peneliti selanjutnya.

\section{Model Pendekatan}

Dalam diagramatik ini petani cabai merah keriting mengelolah kegiatan usahatani cabai merah keriting, usahatani lain dan luar usahatani dari usahatani ini nanti akan diperoleh efisiensi pemasaran pada akhirnya akan mendapatkan kontribusi pendapatan keluarga, lebih jelasnya dapat dilihat Gambar 1:

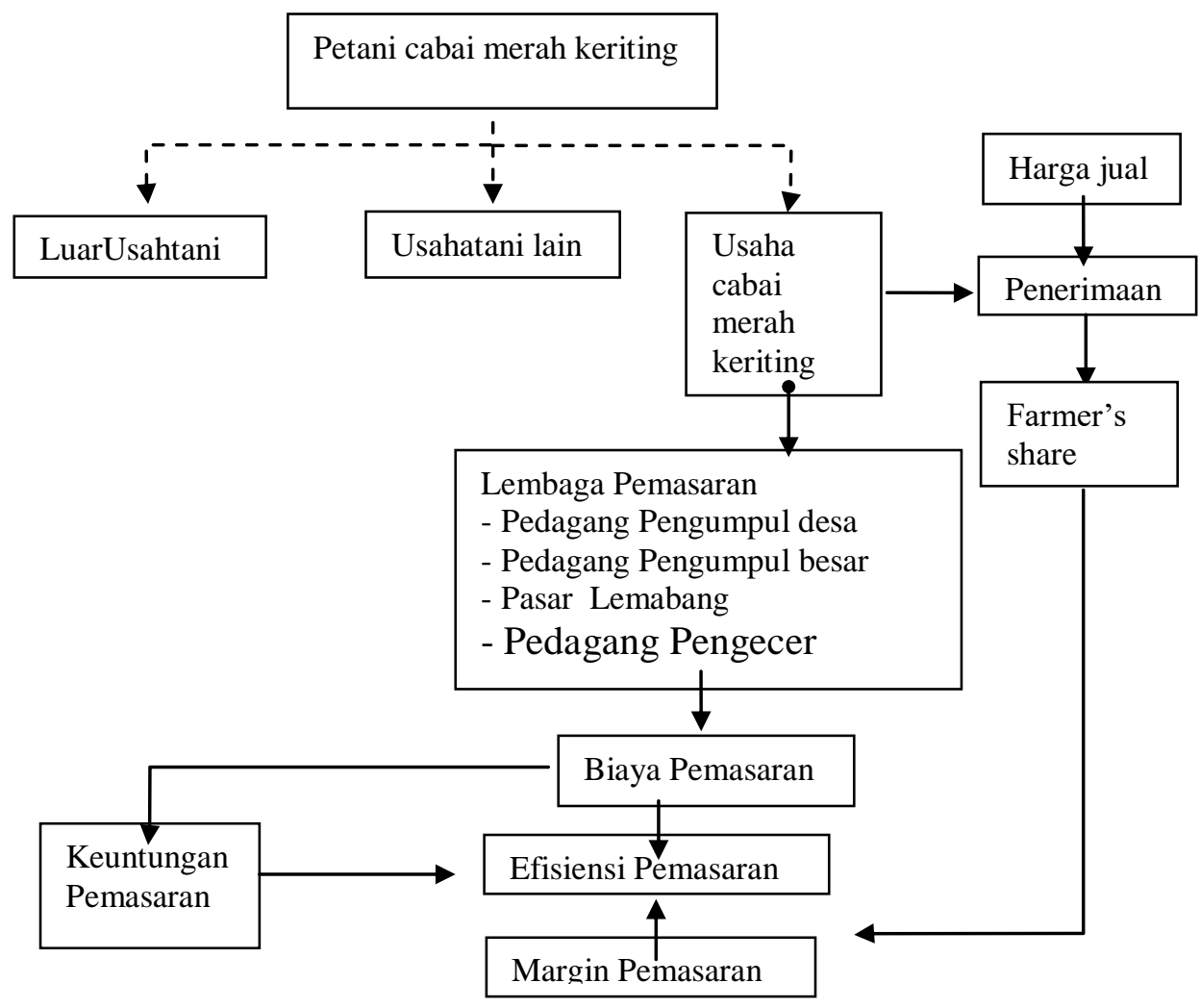

Keterangan :

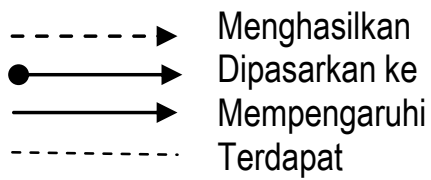

Gambar 1. Model pendekatan secara diagramatik hubungan usahatani cabai meah keriting dengan efisiensi dan kontribusi pendapatan keluarga. 


\section{Batasan-batasan}

1) Petani yang diambil sampel adalah petani yang berusahatani cabai merah keriting Kelurahan Sei Selincah Kecamatan Kalidoni Kota Palembang.

2) Saluran Pemasaran adalah suatu kegiatan penyaluran komoditi cabai merah keriting dari petani produsen ke lembaga pemasaran sehingga sampai ke konsumen.

3) Lembaga pemasaran adalah badan atau pihak-pihak yang memasarkan komoditi Cabai Merah Keriting di Kelurahan Sei Selincah .sampai ke konsumen yaitu pedagang pengempul desa, pedagang besar, pasar lemabang, dan pedagan pengecer.

4) Farmer's share adalah harga yang diterima petani Cabai Merah Keriting dibagi dengan harga ditingkat konsumen dan dinyatakan dalam persen.

5) Biaya Pemasaran adalah seluruh biaya yang dikeluarkan oleh masing-masing lembaga pemasaran dalam memasarkan Cabai Merah Keriting dari Kelurahan Sei Selincah sampai ke konsumen (Rp/Kg).

6) Margin pemasaran adalah selisih harga jual dengan harga beli komoditi cabai merah keriting pada masing-masing lambaga pemasaran, terdiri dari biaya pemasaran dan keuntungan $(\mathrm{Rp} / \mathrm{Kg})$.

7) Keuntugan adalah balas jasa yang diperoleh masing-masing lembaga pemasaran dan dihitung dari selisih antara margin pemasaran dan biaya

8) Harga ditingkat konsumen adalah harga jual pedagang pengecer atau harga beli konsumen dan berlaku pada saat penelitian (Rp/Kg).

9) Harga cabai merah keriting yang dihitung adalah harga rata-rata yang berlaku pada saat penelitian $(\mathrm{Rp} / \mathrm{Kg})$.

10) Pendapatan keluarga adalah pendapatan usahatani cabai merah keriting ditambah pendapatan usahatani lain, ditambah pendapatan luar usahatani.

11) Kontribusi pendapatan cabai merah keriting adalah pendapatan usahatani cabai merah keriting dibagi dengan Total pendapatan keluarga dikali (100\%)

\section{PELAKSAAN PENELITIAN}

\section{Tempat dan Waktu}

Penelitian ini dilaksanakan di Kelurahan Sei Selincah Kecamatan Kalidoni Kota Palembang, penentuan lokasi secara sengaja (purposive) dengan pertimbagan bahwa Kelurahan Sei Selincah adalah salah satu tempat Petani cabai merah keriting. Penelitian dilaksanakan pada bulan Januari 2020 sampai Febuari 2020.

\section{Metode Penelitian Dan Penarikan Contoh}

Metode penelitian ini menggunakan metode survei. metode penarikan contoh dilakukan secara segaja (purposive) dengan jumlah sample sebanyak 15 petani contoh, sedangkan metode pengambilan lembaga pemasaran menggunakan snowboll sampling (bola salju mengelinding) (Silalah, 2009) Untuk menginditifikasi lembaga yang terkait dalam pemasaran Cabai Merah Keriting harus ditelusuri terlebih dahalu saluran pemasarannya. Lembaga pemasaran terlibat itu adalah pedagang pengumpul desa, pedagang besar, pasar lemabang dan pedagang pengecer.

Dari berbagai lembaga yang terlibat dalam pemasaran Cabai Merah Keriting ini diambil contoh sebagai berikut :

1. Pedagang pengumpul desa sebanyak 1 orang

2. Pedagang pengumpul besar sebanyak 1 orang

3. Pedagang pasar sebanyak 1 orang

4. Pedagang pengecer sebanyak 2 orang

\section{Metode Pengumpulan Data}

Data yang dikumpulkan dalam penelitian ini terdiri dari data primer dan data sekunder. Data primer diperoleh dari informasi yang dikumpulkan melalui wawancara dengan petani contoh dan pedagang dengan mengunakan daftar pertanyaan yang telah disiapkan terlebih dahulu (Singaribum dan Effendi, 2009). Sedangkan data sekunder diperoleh dari dinas instansi yang terkait dalam penelitian .

\section{Metode pengolahan data}

Data yang diperoleh dari lapangan diolah secara tabulasi kemudian dilanjutkan dengan analisis biaya-biaya pemasaran, margin pemasaran dan bagian harga yang diterima petani, Farmer'share (Asmarataka 2012) yang diuraikan secara diskriptif.

Untuk menghitung Margin Pemasaran dari harga yang dibayar konsumen pada berbagai saluran pemasaran :

$$
\mathrm{MP} \quad=\mathrm{Hj}-\mathrm{Hb}
$$


Untuk menghitung keuntungan lembaga pemasaran (Share) dari harga yang di bayar konsumen mengunakan rumus :

$$
\mathrm{KP}=\mathrm{Hj}-(\mathrm{BP}+\mathrm{Hb})
$$

Untuk menhitung bagian harga yang diterima petani dari harga yang dibayar konsumen (Farmer's share) digunakan rumus sebagai berikut : FS $=\frac{\text { Hjp }}{\text { HjA }} \times 100 \%$

\section{Keterangan:}

$\begin{array}{ll}\mathrm{FS} & =\text { Farmer's Share }(\%) \\ \mathrm{HjP} & =\text { Harga jual Petani }(\mathrm{Rp} / \mathrm{Kg}) \\ \mathrm{HjA} & =\text { Harga Jual Akhir }(\mathrm{Rp} / \mathrm{Kg}) \\ \mathrm{MP} & =\text { Margin Pemasaran }(\%) \\ \mathrm{Hj} & =\text { Harga jual }(\mathrm{Rp} / \mathrm{Kg}) \\ \mathrm{Hb} & =\text { Harga beli }(\mathrm{Rp} / \mathrm{Kg}) \\ \mathrm{KP} & =\text { Keuntung lembaga Pemasaran } \\ \mathrm{BP} & =\text { Biaya Pemasaran }(\mathrm{Rp} / \mathrm{Kg})\end{array}$

\section{HASIL DAN PEMBAHASAN}

\section{Identitas Responden}

Identitas Petani sampel merupakan latar belakang untuk mengetahui kondisi petani dalam penelitian. Responden dalam penelitian ini adalah petani cabai merah keriting. Adapun yang termasuk identitas responden tersebut adalah nama, umur, tingkat pendidikan, jumlah anggota keluarga dan lama berusahatani.

\section{Umur Responden}

Faktor umur dapat mempengaruhi kemampuan seseorang, baik kemampuan fisik maupun kemampuan mental. Kemampuan fisik disini menyangkut seseorang dalam bekerja, sedangkan untuk kemampuan mental menyangkut bagaimana cara seseorang berfikir dan menentukan keputusan yang akan diambil. Untuk lebih jelasnya distribusi umur petani sampel ditampilkan pada Tabel 1 .

Tabel 1. Umur Responden Contoh Cabai Merah Keriting di Kelurahan Sei Selincah Kecamatan Kalidoni Kota Palembang, 2020.

\begin{tabular}{rccr}
\hline No. & $\begin{array}{c}\text { Umur } \\
\text { ( Tahun })\end{array}$ & $\begin{array}{c}\text { Jumlah Responden } \\
\text { ( orang ) }\end{array}$ & Persentase (\%) \\
\hline 1. & $25-45$ & 15 & 66,67 \\
2. & $46-65$ & 3 & 20,00 \\
3. & $>65$ & 2 & 13,33 \\
\hline & Jumlah & 20 & 100 \\
\hline
\end{tabular}

Tabel 1 menjelaskan bahwa mayoritas petani yang berusahatani cabai merah keriting di Kelurahan Sei Selincah merupakan petani yang berada pada usia produktif.), usia produktif berada pada usia (25-65) tahun. Dengan kondisi petani yang rata-rata berumur produktif maka diharapkan mampu mengelola usahataninya secara maksimal guna meningkatkan produksi.

\section{Tingkat Pendidikan}

Berdasarkan hasil penelitian, petani contoh pada tempat penelitian memiliki tingkat pendidikan yang bervariasi pada Tabel 2 dapat dilihat bahwa pendidikan petani contoh di Kelurahan Sei Selincah yang terbanyak adalah SD sebesar 8 dengan persentase (53,3 persen) orang. berdasarkan pada tingkat pendidikan formal, rata-rata petani menempuh pendidikan SD, hal ini disebabkan petani di daerah penelitian kurang mementingkan pendidikan, mereka mengandalkan kemampuan merekasendiri dalam berusahatani yang sudah dilakukan dari keluarganya yang turun temurun.

Tabel 2. Tingkat Pendidikan Formal Responden Cabai Merah Keriting di Kelurahan Sei Selincah Kecamatan Kalidoni Kota Palembang, 2020.

\begin{tabular}{cccc}
\hline No. & Pendidikan & $\begin{array}{c}\text { Jumlah } \\
\text { (orang) }\end{array}$ & $\begin{array}{c}\text { Persentase } \\
(\%)\end{array}$ \\
\hline 1. & SD & 8 & 53,3 \\
2. & SMP & 5 & 33,3 \\
3. & SMA & 7 & 13,3 \\
\hline & Jumlah & 20 & 100 \\
\hline
\end{tabular}


Pendidikan merupakan salah satu sarana yang penting dalam usaha meningkatkan produksi. Selain pendidikan formal, pengetahuan mengenai pertanian juga dapat diperoleh dari pendidikan non formal seperti penyuluhan dari balai penyuluhan dan adanya demonstrasi tentang penggunaan alat-alat pertanian yang baru.

\section{B. Saluran Pemasaran Cabai Merah Keriting}

Proses pemasaran cabai merah keriting di Kelurahan Sei Selincah terdiri dari tiga saluran pemasaran: saluran pemasaran I petani memasarkan melalui pedagang pengempul desa, hal ini dikarenakan petani sudah terikat untuk menjual ke pengumpul desa dan pengumpul desa juga langsung jual ke konsumen, saluran yang II petani memasarkan pedagang pengempul besar kemudian ke pedagang pengecer, terakhir ke konsumen, Saluran III petani memasarkan pedagang pengempul besar, kemudian ke pasar lembang, lalu pedagang pengecer dan terakhir ke konsumen, untuk melihat lebih jelasnya pendapatan ditampilkan pada Gambar 2:

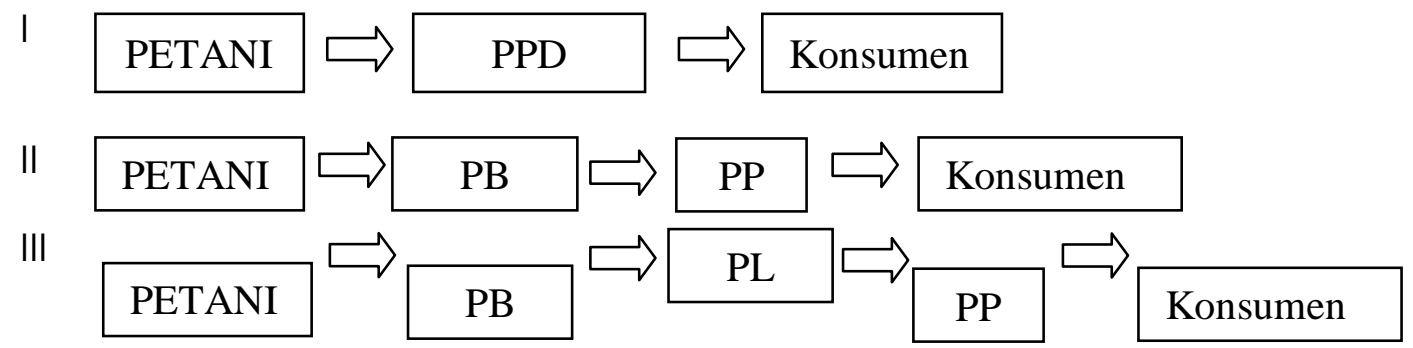

Gambar 2, Berdasarkan Saluran pemasaran cabai merah keriting di Kelurahan Sei Selincah.

Keterangan :

$\begin{array}{ll}\text { PPD } & \text { : Pedagang Pengumpul desa } \\ \text { PB } & \text { : Pedagang Pengumpul Besar } \\ \text { PL } & \text { : Pasar Lembang } \\ \text { PP } & \text { : Pedagang Pengecer }\end{array}$

\section{Farmer's Share Cabai Merah Keriting}

Farmer's share adalah bagian harga yang di terima dibagi harga jual konsumen. Farmer's share dalam suatu kegiatan pemasaran dapat dijadikan dasar atau tolak ukur efisiensi pemasaran. Semakinn tinggi tingkat pemasaran farmer's share yang di terima, maka dikatakan semakin efisien kegiatan pemasarann yang dilakukan dan sebaliknya semakin rendah farmer's share yang diterima, maka akan semakin rendah pula tingkat efisiensi dari suatu pemasaran. Farmer's share pada masing-masimg saluran pemasaran cabai merah keriting di Kelurahan Sei Selincah dapat ditampikan tabel 3.

Tabel 3. Farmer's share yang diterima petani dalam pemasaran Cabai Merah Keriting masing-masing Saluran di Kelurahan Sei Selincah, 2020.

\begin{tabular}{lccc}
\hline Komponen & $\begin{array}{c}\text { Harga jual } \\
\text { Petani }(\mathrm{Rp} / \mathrm{Kg})\end{array}$ & $\begin{array}{c}\text { Harga beli } \\
\text { Konsumen }(\mathrm{Rp} / \mathrm{Kg})\end{array}$ & $\begin{array}{c}\text { Farmer's Share } \\
(\%)\end{array}$ \\
\hline Saluran I & $30.000,00$ & $35.000,00$ & 85,71 \\
Saluran II & $32.000,00$ & $45.000,00$ & 71,11 \\
Saluran III & $32.000,00$ & $55.000,00$ & 58,18 \\
\hline
\end{tabular}


Berdasarkan Tabel 3, diketahui bahwa secara keselurahan baik saluran pemasaran I farmers's Share nya mencapai 85,7 persen dan saluran pemasaran II mencapai 71,1 persen dan di bagian saluran pemasaran III farmers's share nya lebih rendah dari II mencapai 58,8 yang artinya saluran pemasaran I yang lebih tinggi dari saluran pemasaran II.

\section{Margin dan Biaya Pemasaran Cabai Merah Keriting}

Selisih harga dari dua tinngkat rantai pemasaran atau selisih harga yang dibayarkan ditingkat pengecer dengan harga yang diterima oleh produsen (petani). Dengan kata lain, marjin pemasaran menunjukan perbedaan harga diantara tingkat lembaga dalam sistem pemasaran.

Tabel 4. Margin dan Biaya Pemasaran pada Usahatani cabai merah keriting di Kelurahan Sei Selincah sampai kekonsumen akhir pada saluran I, 2020.

\begin{tabular}{lrr}
\hline No Uraian & \multicolumn{2}{c}{ Keterangan } \\
\cline { 2 - 3 } & Harga $(\mathrm{Rp} / \mathrm{Kg})$ & Share $(\%)$ \\
\hline I. Petani & & \\
$\quad$ Harga jual & $30.000,00$ & 85,71 \\
II. Pedagang pengumpul desa & & \\
$\quad$ Harga beli & $30.000,00$ & 85,71 \\
$\quad$ Biaya pemasaran & 570,00 & 1,63 \\
Harga jual & $35.000,00$ & 100 \\
$\quad$ Keuntugan & $4.430,00$ & 12,66 \\
$\quad$ Margin & $5.000,00$ & 14,29 \\
III. Konsumen & & 100,00 \\
$\quad$ Harga akhir & $35.000,00$ & \\
\hline
\end{tabular}

Hal tersebut juga dapat didefisinikan sebagai perbedaan antara apa yang dibayar oleh konsumen dan apa yang diterima oleh produsen dan apa yang diterima oleh produsen untuk produk pertaniannya. Margin pemasaran tediri dari biaya Pemasaran dan keuntungan masing-masing lembaga pemasaran yang memasarkan cabai merah keriting di Kelurahan Sei Selincah Kecamatan Kalidoni. Berdasarkan tabel 4 dapat dijelaskan bahwa petani jual cabai merah keriting kepada pedagang pengumpul desa dengan harga Rp. $30.000,00 / \mathrm{Kg}$ dengan Share 85,71 persen.

Pedagang pengumpul membeli dengan harga Rp.30.000,00/Kg dengan mengelurakan biaya pemasaran sebesar Rp.570,00/Kg terdiri biaya angkut,biaya transportasi, penyusutan cabai merah keriting dan retribusi, penyusutan karung dengan share 1,63 persen. Margin pemasaran pada pedagang pengumpul desa Rp.5.000,00/Kg dengan share 14,29 persen dengan harga jual besar Rp.35.000.,00/Kg dan keuntugan yang diterima pedagang pengumpul desa adalah sebesar $4.430,00 / \mathrm{Kg}$ dengan share mencapai 12,66 persen.

Selanjutnya margin dan biaya pemasaran serta keuntungan pemasaran cabai merah keriting di
Kelurahan Sei Selincah untuk saluran pemasaran II, ditampilkan pada Tabel 5, petani menjual cabai merah keriting dengan pedagang pengumpul besar harga $\mathrm{Rp}, 32.000,00 / \mathrm{Kg}$ dengan share 71,11 persen, dan pengeluarkan biaya pemasaran seperti biaya angkut, biaya transportasi, penyusutan cabai dan retribusi lalu penyusutan karung dengan total biaya Rp.700,00/Kg dengan share 1,58 persen. Margin pemasaran pedagang pengumpul besar Rp.8000,00Kg dengan share 17,78 persen dan mendapatkan keuntungan sebesar Rp.7.300,00/Kg share mencapai 16,22 persen, lalu di beli pedagang pengecer dengan harga $R p .40 .000,00 / \mathrm{Kg}$ dan mengelurkan biaya pemasaran $\mathrm{Rp} .780,00 / \mathrm{Kg}$ meliputi biaya angkut, biaya transportasi retibusi dan penyusutan karung dengan share mencapai 1,73 persen. Margin pemasaran pedagang pengencer Rp.5.000,00/Kg share 11,11 persen, keuntungan pedagang pengecer pencapai Rp.4220,00/Kg dengan share 9,38 persen pengecer pun menjual nya langsung ke konsumen akhir dengan harga Rp.45.000,00/Kg artinya Margin yang lebih besar di terima oleh pedagang pengumpul besar adalah Rp. $8.000,00 / \mathrm{kg}$. 
Tabel 5. Margin dan Biaya Pemasaran pada Usahatani Cabai Merah Keriting di Kelurahan Sei Selincah sampai kekonsumen akhir pada saluran II, 2020.

\begin{tabular}{lrr}
\hline No Uraian & \multicolumn{2}{c}{ Keterangan } \\
\cline { 2 - 3 } & Harga (Rp/Kg) & Share (\%) \\
\hline I. Petani & $32.000,00$ & 71,11 \\
$\quad$ Harga jual & & \\
II. Pedagang pengumpul besar & $32.000,00$ & 71,11 \\
$\quad$ Harga beli & 700,00 & 1,56 \\
$\quad$ Biaya pemasaran & $40.000,00$ & 88,89 \\
$\quad$ Harga jual & $7.300,00$ & 16,22 \\
$\quad$ Keuntugan & $8.000,00$ & 17,78 \\
$\quad$ Margin & & \\
III. Pedagang pengecer & $40.000,00$ & 88,89 \\
$\quad$ Harga beli & 780,00 & 1,73 \\
$\quad$ Biaya pemasaran & $45.000,00$ & 100,00 \\
$\quad$ Harga jual & $4.220,00$ & 9,38 \\
$\quad$ Keuntungan & $5.000,00$ & 11,11 \\
$\quad$ Margin & & 100,00 \\
IV.Konsumen & & \\
$\quad$ Harga akhir & $45.000,00$ & \\
& & \\
\hline
\end{tabular}

Selanjutnya untuk margin dan biaya cabai merah keriting di Kelurahan Sei Selincah untuk pemasaran serta keuntungan lembaga pemasaran saluran pemasaran III.ditampilkan pada tabel 6 .

Tabel 6. Margin dan Biaya Pemasaran Usahatani Cabai Merah Keriting di Kelurahan Sei Selincah sampai kekonsumen akhir pada saluran III .

\begin{tabular}{lrr}
\hline No Uraian & \multicolumn{2}{c}{ Keterangan } \\
\cline { 2 - 3 } & Harga $(\mathrm{Rp} / \mathrm{Kg})$ & Share $(\%)$ \\
\hline I. Petani & $32.000,00$ & 58,18 \\
$\quad$ Harga jual & & \\
II. Pedagang pengumpul besar & $32.000,00$ & 58,18 \\
$\quad$ Harga beli & 880,00 & 1,60 \\
$\quad$ Biaya pemasaran & $42.000,00$ & 76,36 \\
$\quad$ Harga jual & $9.120,00$ & 16,58 \\
$\quad$ Keuntungan & $10.000,00$ & 18,18 \\
$\quad$ Margin & & \\
III. Pasar lemabang & $42.000,00$ & 76,36 \\
$\quad$ Harga beli & 550,00 & 1,00 \\
$\quad$ Biaya pemasaran & $50.000,00$ & 81,82 \\
$\quad$ Harga jual & $7.450,00$ & 13,55 \\
$\quad$ Keuntungan & $8.000,00$ & 14,55 \\
$\quad$ Margin & & \\
IV.Padagang pengecer & $50.000,00$ & 90,91 \\
$\quad$ Harga beli & 770,00 & 7,69 \\
$\quad$ Biaya pemasaran & $55.000,00$ & 100,00 \\
$\quad$ Harga jual & $4.230,00$ & 7,67 \\
$\quad$ Keuntungan & $5.000,00$ & 9,09 \\
$\quad$ Margin pemasaran & & 100,00 \\
V. Konsumen & $55.000,00$ & \\
$\quad$ Harga akhir & &
\end{tabular}




\section{Jurnal Ilmu Pertanian Agronitas Vol. 2 No.2 Edisi Oktober 2020}

Berdasarkan Tabel 6 bahwa di jelaskan pada saluran III ini, petani di Sei Selincah menjual cabai merah keritin dengan harga Rp.32.000,00/Kg dan pedagang pengumpul besar membeli dengan harga Rp.32.000,00/Kg dengan share 58,18 mengeluarkan biaya angkut, biaya transportasi dan penyusutan cabai, retribusi penyusutan karung dengan total biaya $\mathrm{Rp} .880,00 / \mathrm{Kg}$ share 1,60 persen.

Margin pemasaran yang diterima pedagang besar Rp.10.000.00/Kg Share 18,18 persen dan keuntungan yang diterima Rp.9.120,00/Kg dengan harga jual Rp.42.000,00/Kg, Selanjutnya Pedagang besar menjual kepasar lemabang dengan harga Rp.42.000,00/Kg dengan share 76,36 persen, dengan mengeluarkan biaya Rp.550,00/Kg meliputi biaya angkut, biaya transportasi dan penyusutan cabai, retribusi dan penyusutan karung. Margin pemasaran yang diterima sebesar Rp.8.000,00/Kg atau share 14,55 persen dan keuntungan lembaga yang diterima sebesar Rp.7.450,00/Kg dan share 13,55 persen harga jual pedagang pasar lemabang dengan harga Rp.50.000,00/Kg dengan share 90,91 persen.

Melalui pasar lemabang, pedagang pengecer membeli cabai merah keriting dengan harga $\mathrm{Rp} .50 .000,00 / \mathrm{Kg}$ dengan share 90,91 persen, dengan biaya pemasaran sebesar Rp.770,00/Kg. Adapun margin yang diterima oleh lembaga pemasaran Rp.5.000,00/Kg atau share 9,09 persen. Keuntungan yang diterima pedagang pengecer Rp.4.230,00/Kg dan share 7,69 persen dengan harga jual cabai merah keriting kekonsumen akhir sebesar Rp.55.000,00/Kg atau share 100 persen.

\section{KESIMPULAN}

Berdasarkan hasil penelitian dan pembahasan, maka dapat ditarik kesimpulan sebagai berikut :

1. Hasil penelitian adalah bahwa ada 3 saluran pemasaran cabai merah keriting di Kelurahan Sei Selincah terdiri dari tiga saluran pemasaran yaitu a) petani-pedagang pengepul desa-konsumen, $b$ ) petani - pedagang besar - pedagang pengecer konsumen, c) petani - pedagang pengepul besar - pasar lemabang - pedagang pengecer konsumen.

2. Biaya pemasaran saluran 1 adalah Rp.570,00 saluran II Rp.740,00 saluran III Rp. 733,33, Margin pemasaran saluran I Rp.5000,00, saluran II Rp.6.500,00 dan saluran III Rp. 7.667,00 selanjutnya farmer share pada saluran I 85,7 di ikuti saluran II 71,1 dan saluran III 58.82.

\section{DAFTAR PUSTAKA}

Abd, Rahim dan Diah Retno Dwi Hastuti. 2007. Ekonomika Pertanian, Pengantar Teori dan Kasus, Penebar Swadaya. Jakarta.

Asmarantaka, Ratna W. 2012 Pemasaran Agribisnis. IPB-Press. Bogor

Assuari, 2008. Manajemen Pemasaran Pasar Konsep Strategi. Rajawali Press. Jakarta.

Balai Penelitian dan Pengembangan Pertanian. www. Litbang.Pertanian.go.id 2015.Jakarta.

Dirjen Bina Produksi hortikultura, Dapertemen Pertanian. 2003. Jakarta.

Kartasapoetra, 2005.Marketing Produk Pertanian dan Industri.Rinerka Cipta. Jakarta.

Kotler. 2006. Manajemen Pemasaran. Rajawali press. Jakarta.

Kotler, Susanto, 2000. Manajemen Pemasaran Pertanian di Indonesia. Salemba Empat. Jakarta.

Nazarudin. 2005. Budidaya Pegaturan Panen Sayuran Dataran Rendah. Penebar Swidaya. Jakarta.

Nafarin, M. 2009. Penganggaran Perusahaan. Penerbit Salemba Empat. Jakarta.

Muhammad Firdaus, 2009. Manajemen Agribisnis. Penerbit : PT. Bumi Aksara : Jakarta.

Mulyadi. 2007. Akuntansi Manajemen, Konsep, Manfaat, dan Rekayasa. Universitas Gadjah Mada. Yogyakarta.

Mosher. AT, 2002. Menggerakan dan Membangun Pertanian. Bumi Aksara, Jakarta.

Miskun A.R. 2013. Ketahanan Kultivar Cabai Merah (Capsicum Annul L) Terhadap Jamur Colletotrichum Capsici (Syd.) Butler \& Bisby Penyebab Penyakit Antraknosa. Lampung (skripsi tidak dipublikasikan)

Nasution, A.H. danBarizi. 2004. MetodeStatistik. PT. Gramedia. Jakarta.

Rostini, N. 2011. Enam Jurus Bertanaman Cabai Bebas Hama danPenyakit. Agro media. Jakarta.

Santika dan Adhi, 2016. Agribisnis Cabai. Penebar Swadaya. Jakarta

Saefuddin. 2004. Pamasaran Industri Pertanian Bogor. Pustaka Pelajar. Bogor.

Soekartawi. 2002. Pembanguan Pertanian. Raja Grafindo Persada. Jakarta. 
Singarimbun.M dan S. Effendi. 2009. Metode Penelitian Survei, LP3ES. Jakarta.

Silalah, Ulber. 2009. Metode Penelitian Sosial. PT. Refika Aditama. Bandung.

Suharjono, 2016. Akuntansi Perbankan. Edisi I. Salemba Empat. Jakarta.
Suroto. 2000. Strategi Pembangunan dan Perencanaan Perencanaan Kesempatan Kerja. Gadjah Mada Universitas. Yogyakarta. Wiryanta, W. T. 2011. Panduan Lengkap Budidaya dan Bisnis Cabai. PT.Agromedia. Jakarta. 